Sergio Koifman 1

Iara Ferraz 2

Trajano S. Viana 3,4

Carmen L. P. Silveira 5

Maria T. D. Carneiro 5

Rosalina J. Koifman 1

Paula N. Sarcinelli 1

Rita de Cássia O.C. Mattos ${ }^{1}$

Jaime S. Lima ${ }^{8}$

Jefferson J.O. Silva 1

Josino C. Moreira 1

Maria de Fátima A. Ferreira 6

Chester Fernandes 7

Antonio Carlos Bulcão 7

\section{Cancer cluster among young Indian adults living near power transmission lines in Bom Jesus do Tocantins, Pará, Brazil}

\author{
Agrupação de casos de câncer em adultos \\ jovens indígenas residindo nas proximidades \\ de linhas de transmissão de alta tensão elétrica \\ em Bom Jesus do Tocantins, Pará, Brasil
}

1 Escola Nacional de Saúde Pública, Fundação Oswaldo Cruz. Av. Leopoldo Bulhões, 1480, Rio de Janeiro, $R J$ 21041-210, Brasil koifman@dcc001.cict.fiocruz 2 Centro de Trabalho Indigenista. Rua Fidalga 548, sala 14, São Paulo, SP 05432-000, Brasil.

3 Escola Naval. Av. Almirante Sílvio de Noronha s/no, Ilha de Villegaignon, Rio de Janeiro, RJ, 20021-010, Brasil.

4 Centro Federal de Tecnologia (CEFET).

Av. Maracanã , 229, Rio de Janeiro, $R J$ 20271-110, Brasil.

5 Departamento de Química Pontifícia Universidade Católica do Rio de Janeiro. Rua Marquês de São Vicente, 225, Rio de Janeiro, RJ 22453-900, Brasil.

6 Departamento de Biologia Celular e Genética.

Faculdade de Ciências Médicas, Universidade do Estado do Rio de Janeiro. Av. Professor Manoel de Abreu 48, Rio de Janeiro, RJ, 20271-110, Brasil.

7 Eletrobrás. Rua da Quitanda 196, 6o andar, Rio de Janeiro, RJ, 20091-000, Brasil.

8 Departamento de Ciências Fisiológicas, Bioquímica,

Universidade do Rio de Janeiro (Unirio). Rua Frei Caneca 94, 4 o andar, Rio de Janeiro, $R J$ 20211-040, Brasil.

\begin{abstract}
A case study was carried out to explore the occurrence of a cancer cluster in 1992 among young indian adults living in an Amazonian village near two $500 \mathrm{kV}$ power transmission lines that began operating a decade ago. Current blood levels of DDT and organophosphorus pesticides and metal levels in hair samples were measured. Extremely low magnetic field exposure was determined during current daily activities carried out by the Indian villagers. Taking into account the cancer incidence rates in different Brazilian cities, the probability of the occurrence of this cluster by chance was considered remote ( $p<0.003$, Poisson distribution). High blood levels of p, $p^{\prime}$-DDT (median levels ranging from 26 to $58 \mathrm{ppb}$ ) were observed. As a whole, this community showed a pattern of low exposure to organophosphorus pesticides, and high recent exposure was only observed in a few blood samples. Continuous exposure to extremely low electromagnetic fields originated in the power transmission lines (which reached $95.0 \mathrm{mG}$ under the lines) was observed on several opportunities during daily activities carried out by Indian villagers. Further observational studies should evaluate the interaction between exposure to extremely low electromagnetic fields and prior exposure to tumor initiators in cancer development.

Key words Neoplasms; DDT; Pesticides; Electromagnetic Fields; South American Indians
\end{abstract}

Resumo Um estudo de caso foi desenvolvido para avaliar a ocorrência de um agrupamento de casos de câncer em 1992, que se verificou em adultos jovens indígenas vivendo em aldeia na Amazônia, situada nas proximidades de duas linhas de transmissão de $500 \mathrm{kV}$, as quais começaram a operar em 1982. Determinaram-se os níveis sangüíneos atuais de DDT e pesticidas organofosforados, assim como a presença de metais em amostras de cabelo. A exposição a campos eletromagnéticos de freqüência extremamente baixa foi determinada durante diversas atividades diárias desenvolvidas pelos indígenas. Considerando-se a incidência de câncer em diferentes cidades brasileiras, a probabilidade de ocorrência ao acaso deste agrupamento de casos foi considerada remota ( $p<0,03$, distribuição de Poisson). Niveis elevados de p,p'-DDT (mediana variando entre 26 e 58 ppb) foram observados nas amostras estudadas. A exposição contínua aos campos eletromagnéticos de freqüência extremamente baixa, a qual atingiu 95 m G abaixo das linhas de transmissão, foi observada em diversas oportunidades durante atividades diárias desenvolvidas pelos indigenas. Estudos observacionais futuros deveriam analisar a interação da exposição aos campos eletromagnéticos de freqüência extremamente baixa (50-60 Hz) subseqüente à exposição a agentes de iniciação tumoral no desenvolvimento de neoplasias.

Palavras-chave Neoplasias; DDT; Praguicidas; Campos Eletromagnéticos; Índios Sul-Americanos 


\section{Introduction}

The occurrence of cancer among Brazilian indian nations has been scarcely reported in the literature. An active search of cancer cases during an exploratory survey carried out in the late 1950s in several Indian settlements in Brazil failed to observe any cancer cases (Campos, 1961). Since then, mortality from sporadic cases of cancer at different anatomic sites has been mentioned by FUNAI, the Brazilian government agency for Indian affairs (unpublished data).

Parkatêjê Indians ("the people who live on the southern bank of the river" in the Gê-Timbira language, or "Gavião", the Brazilian nickname meaning "Hawk" in Portuguese) have been living since the mid-1970s in the MãeMaria Indian Area (MMIA), in the Brazilian Eastern Amazon Region (Figure 1). Three main communities of this Indian nation, formerly living in different geographical areas, were forced to resettle together following mandatory relocation by government authorities in the late 1960s. Relocation was thus enforced and justified by the government as a measure to allow for the development of new large-scale engineering projects, such as a long highway crossing the Amazon jungle (the Transamazonian Highway) and the Tucuruí Hydroelectric Plant in the State of Pará. Since then, and facing virtual extinction as a consequence of severe malnutrition and widespread dissemination of infectious diseases, the Parkatêjê Indians have been attempting to expand their population by stimulating an increase in their birth rate. They have been relatively successful in this attempt and had 306 inhabitants living in the MMIA in 1992.

Cancer was unknown among Parkatêjê Indians until 1992, when a cluster of three cases was reported in their village (Vieira Filho, 1994). The cases were a 22 -year-old man with acute lymphoblastic leukemia, a 20 -year-old woman with leiomyosarcoma, and a 55 -yearold woman with uterine cervical cancer, all of whom with histopathological confirmation.

The occurrence of these cancer cases raised great discomfort among the Parkatêjê Indians, considering both the previous absence of cancer reports in the community and their uncomfortable and distrustful past experience with Brazilian society. Even after undesired resettlement in MMIA, the community was virtually forced to allow the construction of a railway and two power transmission lines crossing their lands (Figure 2). Moreover, the preserved rain forest in MMIA lands, a green island in the middle of a devastated area of cattle farms, is routinely invaded illegally by woodcutters, creating permanent tension with the Parkatêjê. Thus, the outcome of these cancer cases was almost immediately interpreted by the Parkatêjê as associated to new environmental pollutants introduced through this conflictive contact with the Brazilian society.

In addition, severe ethical concerns were raised following the outbreak of cancer cases (related, for instance, to medical procedures such as the leg amputation once suggested for the young mother with soft tissue sarcoma). A broad discussion thus began surrounding the events possibly associated with these new cancer cases; a search began for different exposures recently introduced into their environment and potentially related to these cancer cases. They included exposure to extremely low electromagnetic fields (EMF) originating from two $500 \mathrm{kV}$ transmission lines crossing the MMIA and starting operations in 1982, a matter of great concern among the Parkatêjê. Other risk factors such as pesticides (never used by the Parkatêjê but widely employed in farms surrounding the MMIA) were also suspected.

This paper presents the conclusions of a technical report prepared by a interdisciplinary team which conducted an epidemiological case study trying to evaluate the impact of different environmental exposures possibly associated with the aforementioned cancer cluster.

\section{Methods}

Taking into account that cervical cancer is the most common form of cancer among women in the poorest areas of the Brazil, including the Amazon Region, we mainly focused on the occurrence of the other two rarer cancer cases observed among young adults. First, a statistical evaluation on the probability of occurrence of both cancer cases by chance was ascertained (Poisson distribution) and by comparing the cancer incidence rates among Parkatêjê 20-29-year-old and those in the general population in the same age group.

Medical antecedents of both young cancer cases including exposure to ionizing radiation were investigated and their relatives interviewed. Exposure to natural radiation in the MMIA was estimated by previous available geological survey data.

Exposure to organochloride (DDT) and organophosphorus pesticides (OPH) was evaluated, respectively, by p,p'-DDT and butyryl- 


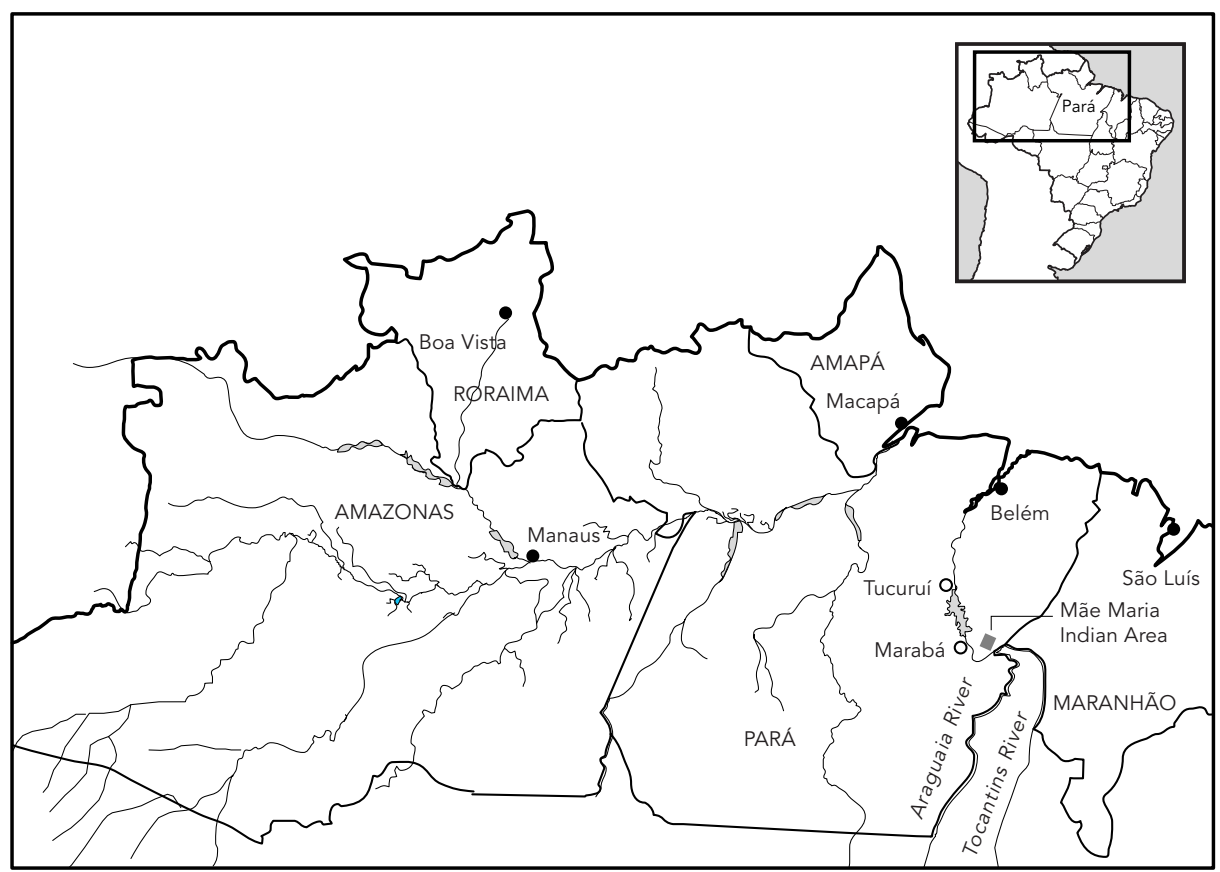

cholinesterase plasma levels ascertained from 89 individual blood samples. Plasma was separated by centrifugation of blood samples, and chromatographic analysis carried out to ascertain p.p'-DDT levels. Butyrylcholinesterase analysis was carried out according to Ellman et al. (1961).

Metal contamination was estimated by trace-element levels ascertained from 14 hair samples by mass spectrometry, which enables one to precisely ascertain the content in hair of more than 70 elements in concentration levels ranging below ppb (Harrison et al., 1969; Nojiri et al., 1989).

EMF exposure was ascertained during current community activities carried out in the village and in several sites located at a close distance or just below the overhead transmission lines (ritual races, farming, fishing, cattle herding, and praying at the cemetery). Spot and 24hour magnetic field direct measurements (obtained with an AMEX meter; Electric Power Research Institute, 1990) were conducted over the course of six days at standardized times and locations at variable distances from the transmission lines. EMF spot measurements, taken at a close distance from the transmission lines, were further compared with estimated fields calculated from data for the same days provid- ed by the utility company running the power lines (Figure 3), and their correlation coefficient was determined. Magnetic fields were ascertained after measurements taken one meter above ground in three orthogonal axes (Bx, By, and $\mathrm{Bz}$ ), while the measured field $\mathrm{B}$ was obtained using the following equation:

$$
\mathrm{B}=\sqrt{ } \mathrm{Bx}^{2}+\mathrm{By} \mathrm{y}^{2}+\mathrm{Bz}^{2}
$$

\section{Results}

A census carried out in 1992 at the MMIA revealed that 44 adults in the 20-29-year age group were living in the community. By comparison with the observed cancer incidence rate in the same age group in Porto Alegre (168.2 per 100.000 in 1991), the Brazilian city with the highest cancer incidence rates (Koifman, 1995), the probability (Poisson distribution) of the occurrence of two cancer cases by chance in this age group among the Parkatêjê was less than 0.003 (three per thousand).

Both young cancer cases, as reported by their parents in direct interviews, grew up healthy with no antecedents of X-ray treatment. According to a previous comprehensive geological survey conducted in the Amazon Region (Carvalho, 1977), natural radioactivity 
Figure 2

Mãe Maria Indian Area. Facilities and natural resources. Bom Jesus do Tocantins, Pará, Brazil.
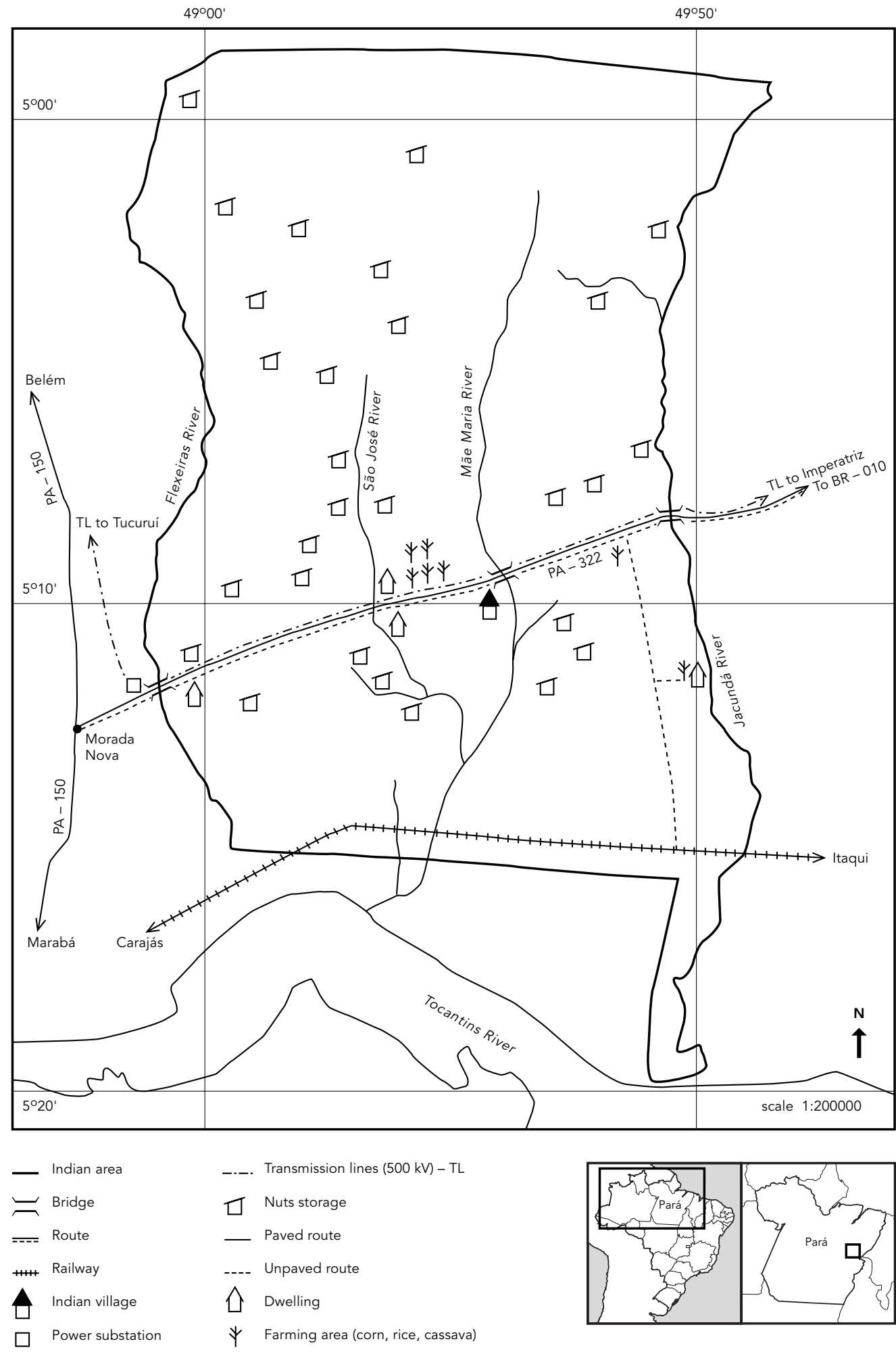


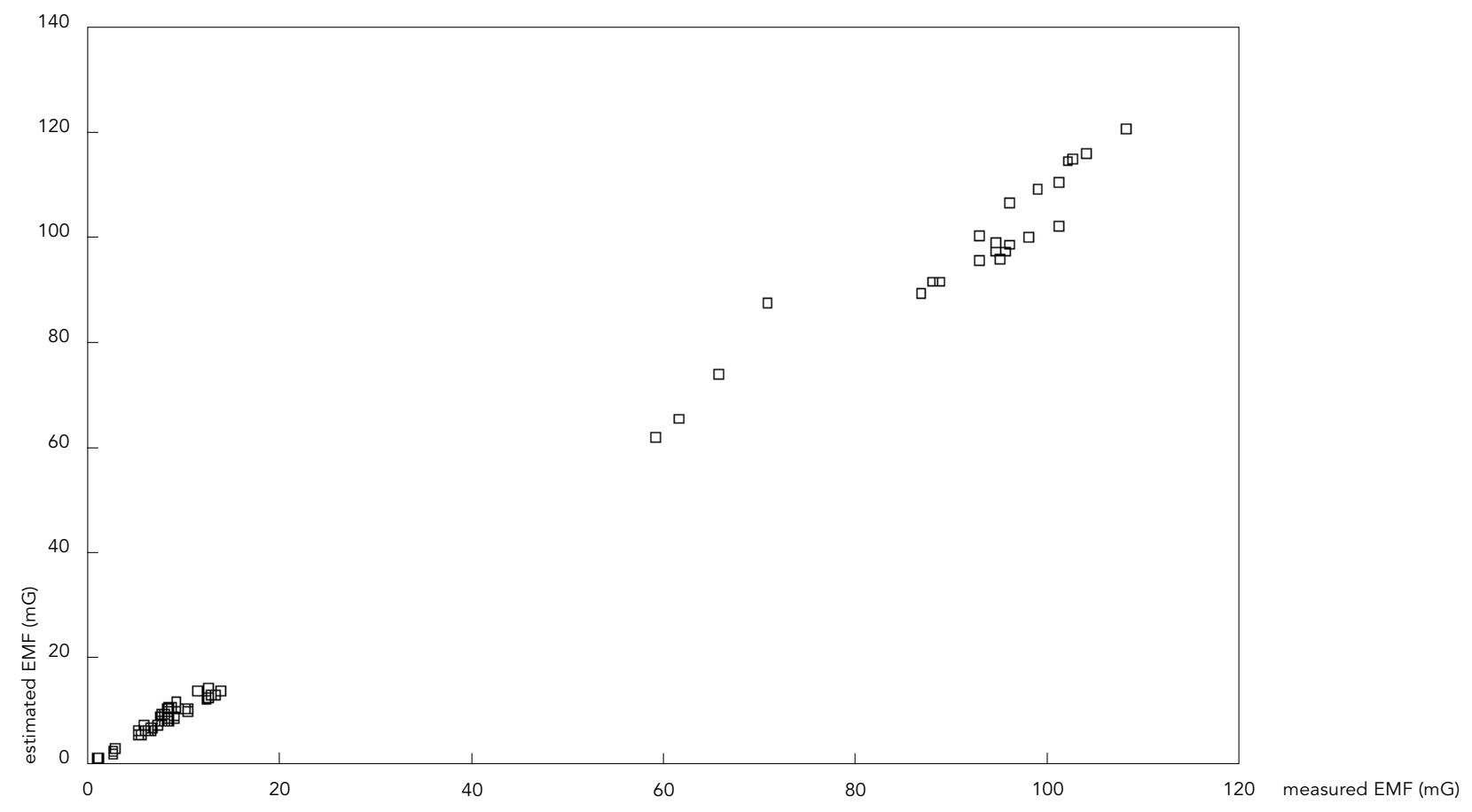

levels are low in Bom Jesus do Tocantins County where the MMIA Parkatêjê village is located.

Median concentration of metals in hair samples are presented at Table 1.

High levels of toxic metals such as lead $(\mathrm{Pb})$, mercury (Hg), cadmium (Cd), silver (Ag), arsenic (Ar), aluminum ( $\mathrm{Al}$ ), and nickel $(\mathrm{Ni})$ were not observed among the Parkatêjê. On the other hand, higher levels of barium (Ba), magnesium (Mg), manganese (Mn), and strontium (Sr) were observed when compared with general population controls.

Mean butyrylcholinesterase plasma level among the Parkatêjê was 5.0 (2.6-7.4) $\mathrm{mM} / \mathrm{ml}$, thus not suggesting recent contamination by organophosphorus pesticides (Table 2). Moreover, median levels of plasma p,p'-DDT ranged from $26.3 \mathrm{ppb}$ (men 30 years of age or older) to $58.1 \mathrm{ppb}$ (children), higher than reported in the literature and suggesting past exposure to DDT (Table 3). No cases of birth defects were reported in the Parkatêjê community.

In relation to EMF exposure, personal cumulative exposure to magnetic fields (Table 4) showed low levels of exposure (below $1.0 \mathrm{mG}$ ) in $62 \%$ of measurements, and moderate levels
(1.0-1.9 mG) were observed in 33\% (7 persons, all of them young adults). Magnetic-field mean exposure during ritual races (20-30 minutes) carried out crossing the transmission lines right-of-way daily was $3.5 \mathrm{mG}$, and $6.8 \mathrm{mG}$ as observed with cattle herders working under the lines. Right-of-way measurements taken at places where children routinely play and fish over a bridge on Route PA 322 ranged from 8.7 to $12.8 \mathrm{mG}$. Transmission lines were built crossing over a preexisting indigenous cemetery where ritual prayers are often performed, and mean exposure to magnetic fields in the cemetery was $95.0 \mathrm{mG}$.

Another set of magnetic field measurements, obtained at standardized times and locations at different distances from the transmission lines, was compared with data provided by the utility company running the transmission lines (Table 5). These comparisons yielded a correlation coefficient of 1.0 (1.0-1.0) based on 78 different measurements (Figure 3). 
Table 1

Median metal concentrations (mineralogram) determined from hair samples, Parkatêjê Indians (Bom Jesus do Tocantins) and urban controls (Rio de Janeiro), Brazil, 1994.

\begin{tabular}{|c|c|c|}
\hline Metal & Parkatêjê (mg/g) & Controls $(\mathrm{mg} / \mathrm{g})$ \\
\hline $\mathrm{Pb}$ & 3.93 & $<10.0$ \\
\hline $\mathrm{Hg}$ & 1.83 & $<2.0$ \\
\hline $\mathrm{Cd}$ & 0.05 & $<0.5$ \\
\hline $\mathrm{Ag}$ & 0.05 & 0.9 \\
\hline $\mathrm{Ba}$ & 37.98 & $<3.7$ \\
\hline As & 0.04 & 0.4 \\
\hline $\mathrm{Al}$ & 13.34 & $<18.0$ \\
\hline $\mathrm{Ni}$ & 0.49 & 1.1 \\
\hline $\mathrm{Bi}$ & 0.05 & - \\
\hline $\mathrm{Na}$ & 118.8 & - \\
\hline K & 16.7 & - \\
\hline$P$ & 551.9 & $156.0-258.0$ \\
\hline B & 0.5 & - \\
\hline $\mathrm{Ca}$ & $1,187.0$ & $151.0-655.0$ \\
\hline $\mathrm{Mg}$ & 192.4 & $12.0-34.0$ \\
\hline V & 0.08 & $<0.012$ \\
\hline $\mathrm{Cr}$ & 0.72 & $0.2-0.4$ \\
\hline $\mathrm{Fe}$ & 28.43 & $8.0-24.0$ \\
\hline $\mathrm{Mn}$ & 2.0 & $0.1-1.1$ \\
\hline $\mathrm{Cu}$ & 11.09 & $11.0-33.0$ \\
\hline $\mathrm{Zn}$ & 149.0 & $145.0-223.0$ \\
\hline Mo & 0.06 & $0.03-0.07$ \\
\hline $\mathrm{Sr}$ & 14.34 & $0.6-3.8$ \\
\hline $\mathrm{Se}$ & 2.33 & $0.5-2.3$ \\
\hline $\mathrm{Au}$ & 0.012 & $0.1-0.3$ \\
\hline $\mathrm{Ge}$ & 0.063 & $0.03-0.09$ \\
\hline Co & 0.40 & $0.03-0.08$ \\
\hline
\end{tabular}

Table 2

Plasma butyrylcholinesterase levels (IU/ml)

in Parkatêjê Indians, Bom Jesus do Tocantins, Rio de Janeiro, and Magé, Brazil, 1994.

\begin{tabular}{llcl}
\hline Population & $\mathbf{n}$ & Mean & 95\% C.I. \\
\hline Parkatêjê, PA & 89 & 5.0 & $2.6-7.4$ \\
Rio de Janeiro, RJ & 36 & 3.5 & $1.3-5.7$ \\
Magé, RJ & 21 & 4.0 & $2.2-5.8$ \\
\hline
\end{tabular}

\section{Discussion}

The occurrence of two cancer cases among young adults in a small indian community during the same year is quite unexpected, considering the low incidence of the disease in these groups. Even taking into account eventual underreporting, these cases would be unexpected considering the small number (44 persons) in the age group from which the two cases arose.

If 20-29-year-old Parkatêjê adults had the same cancer incidence as observed in Porto Alegre, the Brazilian city showing the highest cancer incidence, 0.07 cases would be expected in this age group, and the ratio between observed and expected cases would be 28 . From another perspective, 1,190 Indians 20-29 years old would be necessary to expect 2 cases of cancer if the Parkatêjê had experienced the same cancer incidence observed in Porto Alegre. If comparisons were carried out with Belém, capital of the same State of Pará where Bom Jesus do Tocantins is located, and showing an all-cancer incidence rate of 114.0 / 100.000 among 20-29-year-olds in 1987, 1,754 Indians would be necessary to expect 2 cancer cases, rather than the 44 in this age group then living in the MMIA village. Moreover, when comparing mortality data with the neighboring city of Marabá, 43 kilometers from the MMIA (with 21,200 inhabitants 20-29 years old according to IBGE, 1994), the same number of 2 cancer cases was reported in 1987-89 for this entire population age group (MS, 1987, 1988, 1989).

As a whole, these rough estimates suggest that the probability of the occurrence of this cancer cluster by chance is quite remote. Therefore, despite the small absolute number of cases diagnosed with cancer, the possible reasons for their occurrence should be explored.

From an epidemiological point of view, case studies suffer severe constraints in the sense that they usually do not provide enough information to allow further conclusions on causeeffect relationships. Nevertheless, they may be useful as hypothesis-generating studies, to be further evaluated through observational analytical investigations. We thus attempted to explore different exposures which could theoretically be associated with the unusual occurrence of these cases of cancer among young adult Indians.

Several conditions have been mentioned in the literature as risk factors for cancer during early adulthood, such as virus infection, exposure to ionizing radiation, natural radioactivity (radon), heavy metals, and chemical agents 
such as benzene, herbicides, and pesticides. Since the first report on the association between EMF exposure and cancer (Wertheimer \& Leeper, 1979), a large number of investigations on this subject has also been published, despite the controversy which still remains on this matter (Savitz et al., 1993; Savitz \& Ahlbom, 1994; Carpenter, 1994; Linet et al., 1997). The occurrence of a cancer cluster among young adults living near power transmission lines which began operating ten years before the diagnoses, providing a source of various opportunities to EMF daily exposure at different intensity levels, calls attention the setting in which those cases arose.

Despite the fact that the MMIA is settled in a region surrounded by cattle farms, it still maintains large areas of original jungle in which the Parkatêjê gather nuts during the rainy season and go on monthly hunting journeys. Moreover, community races, a highly important ritual in the Parkatêjê culture, are held daily at dawn by nearly all the villagers, who either cross under the power lines going deep inside the jungle or simply wait below them for the two teams coming back, carrying ceremonial logs on their shoulders. Therefore, besides daily EMF exposure, there are abundant opportunities for virus exposure for all community members.

DDT was used in Brazil until 1994 to control malaria transmission, mainly in the Amazon Region where more than $99 \%$ of cases were diagnosed. Around 3,000 tons of this chemical were estimated to have been introduced into this region from 1988 to 1994 (Loyola, personal communication). DDT is a persistent organic environmental pollutant that is either banned or severely restricted in several countries. Nevertheless, it has been used in many areas where malaria mosquito vectors have not yet developed resistance to it.

Even considering restraints on DDT use, its presence is ubiquitous in the environment as a result of chemical and physical properties, intensive application, and persistence, remaining in the soil for many years. DDT has been shown to cause several disorders in wildlife (birds, fish, and others), besides displaying several adverse human health outcomes like carcinogenic and reproductive effects (Wolf et al., 1991, 1993; Woodruff et al., 1994; Ritter et al., 1995).

Since it has been used recently on a large scale in Brazil, DDT and metabolite serum levels can be used to estimate past exposure in the population (Anderson, 1985). An average p,p'DDT serum level of $0.17 \mu \mathrm{g} / \mathrm{l}$, standard devia-
Table 3

Plasma p, $p^{\prime}$-DDT levels (ppb) in Parkatêjê Indians, Bom Jesus do Tocantins, Brazil, 1994

\begin{tabular}{|c|c|c|c|c|c|}
\hline Age & $n$ & $\mathbf{P}_{25}$ & Median & $\mathbf{P}_{75}$ & $\begin{array}{l}\text { Highest } \\
\text { observation }\end{array}$ \\
\hline$<15$ years (both genders) & 13 & 34.2 & 58.1 & 80.0 & 86.6 \\
\hline \multicolumn{6}{|l|}{$15-29$ years } \\
\hline Men & 26 & 21.6 & 30.8 & 58.0 & 173.4 \\
\hline Women & 14 & 17.5 & 34.1 & 137.3 & 545.5 \\
\hline \multicolumn{6}{|l|}{$>29$ years } \\
\hline Men & 22 & 19.6 & 26.3 & 50.9 & 143.3 \\
\hline Women & 14 & 28.5 & 55.6 & 83.2 & 1160.1 \\
\hline
\end{tabular}

$\mathrm{P} 25$ = first quartile

P75 $=$ third quartile

Table 4

Cumulative and mean exposure to magnetic fields during selected routine activities, Parkatêjê Indians, Bom Jesus do Tocantins, Brazil, 1994.

\begin{tabular}{lcccc}
\hline Activity & $\begin{array}{l}\text { Starting } \\
\text { (time) }\end{array}$ & $\begin{array}{l}\text { Ending } \\
\text { (time) }\end{array}$ & $\begin{array}{l}\text { Cumulative } \\
\text { exposure } \\
\text { (mG/h) }\end{array}$ & $\begin{array}{l}\text { Mean } \\
\text { exposure } \\
\text { (mG) }\end{array}$ \\
\hline housekeeping & $6: 00$ & $9: 25$ & 2.3 & 0.7 \\
ritual race & $6: 55$ & $7: 30$ & 2.0 & 3.5 \\
overnight and ritual race & $22: 00$ & $5: 50$ & 7.8 & 1.0 \\
cattle herding & $9: 30$ & $13: 05$ & 24.3 & 6.8 \\
below TL & $15: 45$ & $16: 25$ & 13.4 & 19.9 \\
(I) & $15: 00$ & $15: 50$ & 18.1 & 21.8 \\
(II) & & & & \\
\hline
\end{tabular}

$\mathrm{TL}=$ transmission lines.

I and II = measurement carried out in different days.

tion (s.d.) 6.04, was reported for the unexposed population in Brazil (Carvalho et al., 1989). On the other hand, chlorinated pesticide serum levels ranging from 6.49 to $254.0 \mu \mathrm{g} / \mathrm{l}$ were observed among 51 workers spraying DDT and hexachlorocyclohexane in cocoa farming in Brazil (Carvalho et al., 1989). Serum levels higher than $30 \mu \mathrm{g} / \mathrm{l}$ were also found among workers spraying DDT in the Brazilian malaria control program, 9\% of them with levels even higher than $50 \mu \mathrm{g} / \mathrm{l}$ (Franklin \& Peixoto, 1988). DDT residues were also found among exposed and unexposed women in Ribeirão Preto, SP, Brazil (Matuo et al., 1992).

Bouwman et al. (1991) reported total DDT levels (p,p'-DDT + p.p'-DDE + p,p'-DDD) reaching $140.9 \mathrm{ppb}$ (equivalent to $\mu \mathrm{g} / \mathrm{l}$ ), s.d. 108.3, among serum samples taken from population groups in the Kwazulu region, Africa, where 
Table 5

Magnetic field spot measurements taken at different distances from $500 \mathrm{kV}$ power transmission lines, Mãe-Maria Indian Area, Bom Jesus do Tocantins, PA, Brazil, October 16-21, 1994.

\begin{tabular}{|c|c|c|c|c|c|c|c|c|c|c|c|c|c|c|}
\hline \multirow[t]{2}{*}{ Site } & \multicolumn{2}{|c|}{ Oct 16, 1994} & \multicolumn{2}{|c|}{ Oct 17,1994} & \multicolumn{2}{|c|}{ Oct 18,1994} & \multicolumn{2}{|c|}{ Oct 18,1994} & \multicolumn{2}{|c|}{ Oct 19, 1994} & \multicolumn{2}{|c|}{ Oct 20, 1994} & \multicolumn{2}{|c|}{ Oct 21, 1994} \\
\hline & Meas & Est & Meas & Est & Meas & Est & Meas & Est & Meas & Est & Meas & Est & Meas & Est \\
\hline$A$ & - & - & - & - & 2.8 & 3.2 & 2.7 & 2.8 & 2.6 & 2.4 & 1.2 & 1.3 & 1.0 & 1.4 \\
\hline B & 5.5 & 8.2 & 8.2 & 8.1 & 8.8 & 8.7 & 8.4 & 8.4 & 9.0 & 9.0 & 9.0 & 9.0 & - & 9.7 \\
\hline $\mathrm{C}$ & - & 8.2 & 13.1 & 13.0 & 12.5 & 12.9 & 12.2 & 12.1 & 12.5 & 12.7 & 2.7 & 13.0 & 13.8 & 14.1 \\
\hline$D$ & 61.0 & 65.3 & 93.5 & 96.7 & 95.0 & 97.8 & 87.8 & 91.0 & 87.0 & 90.8 & 94.0 & 95.4 & 100.0 & 101.4 \\
\hline$E$ & 65.0 & 73.4 & 103.0 & 115.0 & 101.5 & 114.3 & 95.0 & 105.8 & 100.0 & 110.0 & 101.0 & 113.7 & 107.0 & 119.7 \\
\hline $\mathrm{F}$ & 58.5 & 61.9 & 94.5 & 96.9 & 93.5 & 98.4 & 86.0 & 88.9 & 92.0 & 94.9 & 92.0 & 95.1 & 97.0 & 99.1 \\
\hline G & 5.2 & 5.6 & 8.0 & 8.4 & 7.9 & 8.3 & 7.7 & 8.1 & 7.9 & 8.3 & 8.1 & 8.4 & 8.8 & 9.3 \\
\hline $\mathrm{H}$ & 5.2 & 6.5 & 7.9 & 9.5 & 7.7 & 9.3 & 7.5 & 9.3 & 7.5 & 9.4 & 7.9 & 9.7 & 8.2 & 10.2 \\
\hline I & 5.7 & 7.3 & 8.5 & 10.8 & 8.3 & 10.6 & 8.1 & 10.4 & 8.2 & 10.5 & 8.6 & 11.0 & 9.2 & 11.9 \\
\hline$J$ & 6.0 & 6.4 & 6.7 & 6.9 & 6.4 & 6.7 & 6.2 & 6.5 & 6.3 & 6.5 & 6.6 & 7.0 & 7.2 & 7.4 \\
\hline
\end{tabular}

$A=$ reference site located $33.5 \mathrm{~m}$ from the outer edge of Route PA - 322; B = outer edge of Route PA-322; C = inner edge of Route PA-322 located $(45.5 \mathrm{~m}$ from $\mathrm{A}) ; \mathrm{D}=$ transmission line right-of-way $(80.5 \mathrm{~m}$ from $\mathrm{A})$; $E=$ below transmission line $(91 \mathrm{~m}$ from $\mathrm{A})$; $F=$ transmission line right-of-way $(102 \mathrm{~m}$ from $\mathrm{A}) ; \mathrm{G}=$ site located $132 \mathrm{~m}$ from $\mathrm{A} ; \mathrm{H}=$ site located $137 \mathrm{~m}$ from $\mathrm{A} ; \mathrm{I}=$ site located $143 \mathrm{~m}$ from $\mathrm{A} ; \mathrm{J}=$ site located $177 \mathrm{~m}$ from $\mathrm{A}$.

Meas $=$ measured fields; Est $=$ estimated fields.

DDT was applied in households to control malaria transmission. In this study, mean p,p'DDT serum levels of $37.3 \mathrm{ppb}$ (s.d. 27.2) were observed among exposed groups.

Pesticide exposure was a constant in the MMIA during previous decades, when DDT was periodically sprayed on the palm roofs of Indian dwellings as a regular activity of the national malaria control program. Moreover, according to this indian community's cultural habits, personal goods such as forks, combs, toothbrushes, etc., are stored on the palm roofs. When the transmission lines were built in the early 1980s, the traditional indian dwellings were replaced by brick houses, and DDT spraying was replaced by that of other insecticides; nevertheless, high serum DDT levels are still observed among the Parkatêjê Indians (Table 3). These levels among the Parkatêjê (a mean of $51.61 \mathrm{ppb}$ in women, s.d. 39.62; $50.53 \mathrm{ppb}$ among men, s.d. 46.79) are comparable to those observed in workers with occupational exposure to DDT in Brazil or the general population exposed in the Kwazulu Region of Africa, and several times higher than seen among unexposed population groups in Brazil.

To evaluate recent exposure to organophosphorus pesticides (OPH) (a major concern considering the proximity between the MMIA and surrounding farms), butyrylcholinesterase (BTC) was measured from blood samples drawn from Parkatêjê community members, since its enzymatic activity has been considered the most appropriate biological indicator of OPH exposure. BTC levels were higher than observed in samples from the general population (non-statistically significant differences, Table 2), thus suggesting a low current exposure to OPH among the Parkatêjê. Nevertheless, quite high levels of exposure to $\mathrm{OPH}$ (plasma BTC below $3.0 \mathrm{IU} / \mathrm{ml}$ ) were indeed seen in $8 \%$ of the samples $(11 \%$ showed levels below $3.5 \mathrm{IU} / \mathrm{ml}$ ).

Distribution of metal in hair samples was measured to evaluate possible exposure to confirmed/suspected carcinogens, such as $\mathrm{Pb}$, $\mathrm{Cr}, \mathrm{Al}$, and $\mathrm{Ni}$. Although only a few samples could be obtained, no elevated traces of these elements were observed. However, higher levels of Ba and Mg than usually observed in urban Brazilian populations were observed systematically in the Parkatêjê, probably resulting from the $\mathrm{Ba}$ - and $\mathrm{Mg}$-rich indigenous diet (nuts and nut "milk") (Tsalev \& Zaprianov, 1984).

Exposure to ionizing radiation has been reported in the literature as an important risk factor for several forms of cancer, including hematological diseases and sarcomas (Miller, 1989). The two young Indians who developed cancer appear to have grown up healthy, never having been submitted to X-ray treatments like those recommended decades ago for acne or tinea capitis. Nevertheless, screening for tuberculosis by fluoroscopy was in fact carried out sporadically in the MMIA.

Exposure to natural radioactivity (radon) has been mentioned in the literature as associated with cancer, mainly lung cancer. Nevertheless, natural radioactivity levels in the entire county where the MMIA is located are consid- 
ered very low. The region as a whole is not located in an anomalous geological area, showing non-radioactive rocks originating in the Maranhão Basin, as reported in a comprehensive geological survey conducted earlier in the Amazon Region by the Companhia de Pesquisa de Recursos Minerais in 1977 (Carvalho, 1977).

Since the first report on the association between EMF exposure and cancer during childhood (Wertheimer \& Leeper, 1979), an impressive number of reports on that association has been published, also including workers undergoing occupational exposure (Thériault et al., 1994; Savitz and Loomis, 1995) and the general population (London et al., 1991; Feychting \& Ahlbom, 1993; Washburn et al., 1994; Savitz \& Ahlbom, 1994). Despite severe criticism due to methodological flaws in several epidemiological studies exploring the association (Savitz \& Ahlbom, 1994), it has not been possible to dismiss the evidence after two decades of intensive research. After all, despite the fact that the incidence of selected cancer sites (mainly leukemia, brain cancer, non-Hodgkin lymphoma, soft-tissue sarcoma, and lung cancer) has been linked to EMF exposure from different sources such as power transmission lines, the causal nature of that association remains controversial, and the debate continues to be raised (Youngson et al., 1991; Kavet et al., 1992; Tenforde, 1992; Verkasalo, 1993; Feychting \& Ahlbom, 1993, Linet et al., 1997).

In 1982, two $500 \mathrm{kV}$ transmission lines were built crossing the MMIA along an unpaved road previously built in this area (Route BR-PA 322). Traffic used to be, and still is, very scarce along this route, hence exposure levels to polyamino-hydrocarbons and other chemicals from motor-vehicle exhaust are very low. Despite the fact that the Parkatêjê village is located 700 meters from the transmission lines, many opportunities for close contact by the villagers have been observed: the lines were built directly over the Parkatêjê cemetery, where praying is often performed; their cattle graze below them; community ritual races are held daily at dawn by virtually all the villagers, who cross under the lines into the jungle and come back carrying heavy logs to the village; community crops (corn, cassava, beans, pumpkin, etc.) are grown along the power line right-ofway; children play and fish from a road bridge located just a few meters away; groups of 20-30 Indian villagers travel daily for an hour along the transmission lines in a community-owned truck to trade in the city of Marabá, 43 kilometers away; and hunting areas and nut groves are also reached by crossing under the lines.
Thus far, an approach to all these possible risk factors for the observed cancer cluster led us to not consider metal contamination, ionizing radiation, or exposure to natural radioactivity very relevant as possible explanations. On the other hand, past exposure to DDT, viruses, and EMF were not to be excluded.

According to the well-demonstrated and scientifically-acknowledged multiple-step model of carcinogenesis, cancer arises following multiple changes in a single normal cell, which experiences irreversible alterations in DNA (cell induction or initiation). The altered cell may remain in this condition for life with no major repercussions. Nevertheless, if other agents continuously stimulate cell division, the altered cell can reproduce, yielding a clone displaying the same genetic modifications (promotion). Although reversible, if stimulation persists, the mass of altered cells grows, leading to an autonomous process to the point where clinical manifestations begin (tumor progression). Different genetic changes participate in the whole process, mainly those involved with cell division enhancement (oncogenes) or inhibition (antioncogenes or tumorsuppressor genes) (Moolgavkar, 1986; Bishop, 1987; Brandt-Rauf \& Pincus, 1987; Hermo, 1987; Weiss, 1990)

According to present knowledge, only a few carcinogenic agents (like ionizing radiation and smoking) are able to lead to the entire process alone and are thus called complete carcinogens. In general, biological studies on cancer development show that several agents take part in different steps, making the overall process the result of several changes produced by different interacting risk factors, leading together to a specific neoplasm.

In the case of the cluster analyzed here, exposure to virus or pesticides, mainly DDT, could theoretically be involved with cancer development alone, i.e., acting as complete carcinogens.

Another possible explanation is that one or both of the above acted as tumor initiators, altering cell DNA and starting a process followed by a promoter stimulation. Among the exposures analyzed in this case study, continuous EMF exposure from the transmission lines at the Parkatêjê settlement could be a candidate. Non-ionizing radiation may have played a role as a cancer promoter, thus stimulating reproduction of a preexisting altered cell, as previously raised as a hypothesis for EMF exposure and cancer (Easterly, 1981; Koifman, 1993).

The anatomical sites in which cancer cases were observed among young Parkatêjê, a 
leukemia and a soft-tissue sarcoma, are both included among those reported in the literature as associated with this type of exposure. Moreover, timing between the start of this exposure (1982) and cancer diagnosis (1992) may be considered consistent in terms of biological plausibility (latency period) expected to be shown for a promoter. In this sense, promoters usually participate in the latter periods of tumor development, closer to clinical onset of disease.

The biological plausibility of EMF involvement in carcinogenesis has also been suggested by other cell mechanisms, such as the subsequent low melatonin levels observed among animals continuously exposed to EMF (Tamarkin et al., 1982; Shah et al., 1984; Stevens, 1994) and the in vitro changes in tumor biomarker levels (adenosine deaminase and ornityl-descarboxylase) in cells also exposed continuously to EMF (Parola and Markel, 1994).

EMF exposure has been studied in several epidemiological surveys in which other environmental risk factors were controlled as possible confounders. As previously mentioned, a case study like ours is not able to test a hypothesis of causal association, but does raise hypotheses for further evaluation. In this sense, the observed cluster of cancer among young
Indians as reported here perhaps indicates a joint action of EMF continuous exposure over time subsequent to DNA change caused by tumor initiators. In this case, the combined action of the two factors could have started the several steps of biological changes leading to the unusual cancer cluster in the indian community. We believe that further studies should focus on the interaction in such joint relationships, little analyzed in combination by previous epidemiological investigation.

\section{Conclusions}

A cancer cluster among young adults was observed in a small indian community in Brazil. The probability that this event occurred by chance was considered remote by the authors. No evidence was observed of metal contamination by $\mathrm{Pb}, \mathrm{Al}, \mathrm{Cd}$, or $\mathrm{Ni}$ or prior exposure to natural radioactivity or ionizing radiation. Evidence of past exposure to DDT and recent minor exposure to organophosphorus pesticides was suggested. Several opportunities for exposure to very low electromagnetic fields originating from electric power transmission lines were also observed during daily activities in this community.

\section{References}

ANDERSON, H. A., 1985. Utilization of adipose tissue biopsy in characterizing human halogenated hydrocarbon exposure. Environmental Health Perspectives, 60:127-131.

BISHOP, J. M., 1987. The molecular genetics of cancer. Science, 25:305-311.

BOUWMAN H.; COOPPAN, R. M.; BECKER P. J. \& NGXONGO, S., 1991. Malaria control and levels of DDT in serum of two populations in Kwazulu. Journal of Toxicology and Environmental Health, 33:141-155.

BRANDT-RAUF, P. W. \& PINCUS, M. R., 1987. Oncogenes and oncogene proteins. In: Occupational Cancer and Carcinogenesis, Occupational Medicine: State of the Art Reviews (P. W. Brandt-Rauf, ed.), pp. 27-38, Philadelphia: Hanley \& Belfus.

CAMPOS, S. S., 1961. Estudos sobre o câncer nos índios do Brasil. Revista Brasileira de Cancerologia, 2:33-50. 
CARPENTER, D. O., 1994. The public health implications of magnetic field effects on biological systems. In: Biological Effects of Electrical and Magnetic Fields (D. O. Carpenter \& S. Ayrapetian, eds.), vol. 2, pp. 321-329, San Diego: Academic Press.

CARVALHO, Y. B., 1977. A contribuição da Companhia de Pesquisa de Recursos Minerais no desenvolvimento do setor mineral. Brasília: Companhia de Pesquisa de Recursos Minerais. (mimeo)

CARVALHO, W. A.; BERBERT, P. R. \& ROCHA, N. V. P., 1989. Avaliação da exposição ocupacional de aplicadores de hexaclorociclohexano na lavoura cacaueira do Estado da Bahia, Brasil. Revista Brasileira de Saúde Ocupacional, 17:50-64.

EASTERLY, C. E., 1981. Cancer link to magnetic field exposure; a hypothesis. American Journal of Epidemiology, 114:169-174.

ELECTRIC POWER RESEARCH INSTITUTE, 1990. The EMDEX Project: Technology, Transfer and Occupational Measurements. Project Description and Results, Portland: T. Dan Bracken. (Publ. EPRI EN7048, Interim Report, vol 2.)

ELLMAN, G. L.; COURTNEY, K. \& FEATHERSTONE, R., 1961. A new abd rapid colorimetric determination of acetylcholinesterase activity. Biochemical Pharmacology, 7:89-95.

FEYCHTING, M. \& AHLBOM, A., 1993. Magnetic fields and cancer in children residing near Swedish high voltage power lines. American Journal of Epidemiology, 7:467-481.

FRANKLIN, H. M. O. H. \& PEIXOTO, T. M. A. G., 1988. Níveis sanguíneos de HCH e DDT em guardas da SUCAM. Revista Brasileira de Toxicologia, 1:6-8.

HARRISON, W. W.; YURACHEK, I. P. \& BENSON, C. A., 1969. The determination of trace elements in human hair by atomic absorption spectrometry. Clinica Chimica Acta, 23:83-91.

HERMO Jr., H., 1987. Chemical carcinogenesis: tumor initiation and promotion. In: Occupational Cancer and Carcinogenesis, Occupational Medicine: State of the Art Reviews (P. W. Brandt-Rauf, ed.), pp. 1-25, Philadelphia: Hanley \& Belfus.

IBGE (Instituto Brasileiro de Geografia e Estatística), 1994. Censo Demográfico do Brasil, 1991. Rio de Janeiro: IBGE.

KAVET, R.; SILVA, J. M. \& THORTON, D., 1992. Magnetic field exposure assessment for adult residents of Maine who live near and far away from overhead transmission lines. Bioelectromagnetcs, 13:35-55.

KOIFMAN, S., 1993. Electromagnetic fields: a cancer promoter? Medical Hypothesis, 41:23-27.

KOIFMAN, S., 1995. Incidência de câncer no Brasil. In: Os Muitos Brasis: Saúde e População na Década de 80 (M. C. S. Minayo, org.), pp. 143-176, São Paulo: Hucitec-Abrasco.

LINET, M. S.; HATCH, E. E.; KLEINERMAN, R. A.; ROBINSON, L. L.; KAUNE, W. T.; FRIEDMAN, D. R.; SEVERSON, R. K.; HAINES, C. M.; HARTSOCK, C. T.; NIWA, S.; WACHOLDER, S. \& TARONE, R. E., 1997. Residential exposure to magnetic fields and acute lymphoblastic leukemia in children. New England Journal of Medicine, 377:1-44.

LONDON, S. J.; THOMAS, D. C.; BOWMAN, J. D.; SOBEL, E.; CHENG, T. C. \& PETERS, J. M., 1991. Ex- posure to residential electric and magnetic fields and risk of childhood leukemia. American Journal of Epidemiology, 134:923-937.

MATUO, Y. K.; LOPES, J. N. C.; CASANOVA, I. C.; MATUO, T. \& LOPES, J. L. C., 1992. Organochlorine pesticide residues in human milk in the Ribeirão Preto region, State of São Paulo, Brazil. Archives of Environmental Contamination and Toxicology, 22:167-175.

MILLER, R. W.,1989. Frequency and environmental epidemiology of childhood cancer. In: Principles and Practice of Pediatric Oncology (P. A. Pizzo \& D. G. Poplack, eds.), pp. 3-18, Philadelphia: J. B. Lippincott.

MOOLGAVKAR, S. H., 1986. Carcinogenesis modeling: from molecular biology to epidemiology. Annual Review of Public Health, 7:151-169.

MS (Ministério da Saúde), 1987. Estatísticas de Mortalidade no Brasil. Brasília: Ministério da Saúde.

MS (Ministério da Saúde), 1988. Estatísticas de Mortalidade no Brasil. Brasília: Ministério da Saúde.

MS (Ministério da Saúde), 1989. Estatísticas de Mortalidade no Brasil. Brasília: Ministério da Saúde.

NOJIRI, Y.; HASEGAWA T. \& TETSUYA, C., 1989. Simultaneous multielementar analysis of certified reference hair material by ICP-AES. Chemical Chu Journal 34:104-108.

PAROLA, A. H. \& MARKEL, A., 1994. Electric and magnetic fields and carcinogenesis. In: Biological Effects of Electrical and Magnetic Fields (D. O. Carpenter \& S. Ayrapetian, eds.), vol. 2, pp. 177-197, San Diego: Academic Press.

RITTER, L.; SOLOMON, K. R.; FORGET, J.; STEMEROFF, M. \& O'LEARY C., 1995. A review of selected persistent organic pollutants. Draft Intern Report: International Program on Chemical Safety. Geneva: World Health Organization.

SAVITZ, D. A. \& AHLBOM, A., 1994. Cancer in relation to residential exposure to electric and magnetic fields. In: Biological Effects of Electrical and Magnetic Fields (D. O. Carpenter \& S. Ayrapetian, eds.), vol. 2, pp. 233-262, San Diego: Academic Press.

SAVITZ, D. A. \& LOOMIS, D. P., 1995. Magnetic field exposure in relation to leukemia and brain cancer mortality among electric utility workers. American Journal of Epidemiology, 141:123-134.

SAVITZ, D. A.; PEARCE, N. \& POOLE, C., 1993. Update on methodological issues in the epidemiology of electromagnetic fields and cancer. Epidemiological Reviews, 15:558-566.

SHAH, P. N.; MHATRE, M. C. \& KOTHARI, L. S., 1984. Effect of melatonin on mammary carcinogenesis in intact and pinealectomized rats in varying photoperiods. Cancer Research, 44:3403-3407.

STEVENS, S., 1994. Electric Power and risk of hormone-related cancers. In: Biological Effects of Electrical and Magnetic Fields (D. O. Carpenter \& S. Ayrapetian, eds.), vol. 2, pp. 263-278, San Diego: Academic Press.

TAMARKIN, L.; DANFORTH, D.; LICHTER, A.; DEMOSS, E.; COHEN, M.; CHABNER, B. \& LIPPMAN, M., 1982. Decreased nocturnal plasma melatonin peak in patients with estrogen receptor positive breast cancer. Science, 216:1003-1005.

TENFORDE, T. S., 1992. Biological interactions and 
potential health effects of extremely-low-frequency magnetic fields from power lines and other common sources. Annual Review of Public Health, 13:173-196.

THÉRIAULT, G.; GOLDBERG, M.; MILLER, A. B.; ARMSTRONG, B.; GUENEL, P.; DEADMAN, J.; IMBERMAN, E.; TO, T.; CHEVALIER, A.; CYR, D. \& WALL, C., 1994. Cancer risks associated with occupational exposure to magnetic fields among utility workers in Ontario and Quebec, Canada, and France: 1970-89. American Journal of Epidemiology, 139:550-572.

TSALEV, D. L. \& ZAPRIANOV, Z. K., 1984. Atomic Absorption Spectrometry in Occupational and Environmental Health Practice. Vol. 1. Boca Ratón: CRC Press.

VERKASALO, P. J., 1993. Risk of cancer in Finnish children living close to powerlines. British Medical Journal, 307:895-899.

VIEIRA FILHO J. P. B., 1994. Malignant tumors among Gavião Indians. Proximity of electromagnetic fields. Revista da Associação Médica Brasileira, 40:137-139.

WASHBURN, E. P.; ORZA, M. J.; BERLIN, J. A.; NICHOLSON, W. J.; TODD, A. C.; FRUMKIN, H. \& CHALMERS, T. C., 1994. Residential proximity to electricity transmission and distribution equipment and risk of childhood leukemia, childhood lymphoma, and childhood nervous system tumours: systemic review, evaluation and analysis. Cancer Causes and Control, 5:299-309.

WEISS, K. M., 1990. Cancer models and cancer genetics. Epidemiology, 1:486-490.

WERTHEIMER, N. \& LEEPER, E., 1979. Electrical wiring configuration and childhood cancer. American Journal of Epidemiology, 129:273-284.

WOLFF, M. S.; RIVERA, M. \& BAKER, D. B., 1991. Detection limits of organochlorine pesticides and related compounds in blood serum. Bulletin of Environmental Contamination and Toxicology, 47:499-503.

WOLFF, M. S.; TONIOLO, P. G.; LEE, E. W.; RIVERA, M. \& DUBIN, N., 1993. Environmental organochlorine exposure as a potential etiologic factor in breast cancer. Journal of the National Cancer Institute, 85:648-652.

WOODRUFF, T.; WOLFF, M. S.; DAVIS, D. L. \& HOYWARD, D.; 1994. Organochlorine exposure estimation in the study of cancer etiology. Environmental Research, 65:132-144.

YOUNGSON, J. H.; CLAYDEN, A. D.; MYERS, A. \& CARTWRIGHT, R. A., 1991. A case-control study of adult haematological malignancies in relation to overhead power lines. British Journal of Cancer, 63:997-985. 